\title{
A INTERVENÇÃO JUDICIAL NA EFETIVAÇÃO DO DIREITO FUNDAMENTAL À EDUCAÇÃO
}

\section{JUDICIAL INTERVENTION IN THE REALIZATION OF THE RIGHT TO THE EDUCATION}

Fernanda Rodrigues Lagares

Lúcia Maria Barbosa Nascimento

\begin{abstract}
RESUMO
A Constituição Federal Brasileira apresenta a educação como um dos direitos fundamentais de caráter social. Apesar disso, e do papel de destaque que esses possuem em nosso ordenamento, a educação é claramente um direito não efetivado na vida de muitos brasileiros, o que acaba por violar a norma constitucional. Diante disso, e partindo do pressuposto de que a garantia à educação é um mecanismo de transformação social, este trabalho, tem como objetivo analisar a intervenção do judiciário na efetivação do direito à educação. Para tanto, encaminhou-se pelo viés da análise documental no site do Supremo Tribunal Federal buscando suas decisões nas ações que discutiam esse direito, após uma básica revisão de literatura. Estudos mostram que, embora - quando provocado - o Poder Judiciário atue pela efetivação do direito à educação, muito ainda tem a fazer para que esse direito seja concretizado em sua plenitude no Brasil.
\end{abstract}

Palavras-chave: Direitos Sociais. Educação. Judiciário.

\begin{abstract}
The Brazilian Federal Constitution presents education as a fundamental right of social character. Despite this and the important role it have in our legal system, the education certainly is a right not effected in the life of many brazilian people, which violates constitutional norm. In reason, on the assumption that the guarantee to education is a social transformation mechanism, this work aims to analyze the intervention of the judiciary in ensuring the right to education. Therefore, headed by the bias of the documentary analysis on the site of the Supreme Court seeking it's decisions on actions that discussing this right after a basic literature review. Studies show that, though - when triggered - the judiciary act by the realization of the right to education, much still has to do to make this right is realized in it's fullness in Brazil.
\end{abstract}

Keywords: Social Rights. Education. Judiciary. 


\section{INTRODUÇÃO}

A atual Constituição Federal Brasileira (1988), fazendo jus ao cognome de Constituição Cidadã, deu grande destaque aos Direitos Fundamentais Sociais e, de forma especial, ao Direito à Educação, que além de previsto expressamente no rol taxativo do artigo $6^{\circ}$, como um dos direitos sociais, possui regulamentação em seção própria do capítulo III da Carta Magna.

Tal imperativo constitucional, leva a um aparente consenso em torno da concepção de que a educação deve ser priorizada pelos governantes. Porém, é notável como a educação é um direito não efetivado para uma grande parte da população brasileira, sobretudo para as classes vulneráveis economicamente ou residentes em regiões periféricas, o que constitui descumprimento de norma constitucional.

Assim, diante dessa violação à Carta Magna e, sobretudo da certeza tanto do Direito quanto da Educação como mecanismos de transformação social, questionase: pode o poder judiciário intervir na efetivação do direito à educação? Como tem sido seu comportamento frente às demandas envolvendo esse direito?

O objetivo central desta pesquisa consiste em examinar se o poder judiciário pode intervir na efetivação do direito à educação e qual tem sido seu comportamento frente às demandas envolvendo esse direito. São objetivos específicos: a identificação se as cláusulas da reserva do possível e do mínimo existencial, apresentadas pela doutrina, são de fato observadas pelo judiciário em suas decisões e, caso existam, quais são os limites auto impostos pelo judiciário em sua atuação pela concretude do direito à educação.

Partindo da ideia de que a ação do judiciário como um todo, é direcionada pelos posicionamentos do Supremo Tribunal Federal, para chegar às conclusões pretendidas realizou-se um levantamento qualitativo de ações que discutiam essa temática no site daquele que é tido como o guardião da Constituição Federal, elegendo como fontes da investigação as decisões com objetos pleiteados distintos entre si e com relevante reconhecimento pela doutrina especializada e pelo próprio Tribunal, conforme as constantes citações das mesmas no trato da matéria.

Adotou-se o método de análise documental na busca de entender 0 comportamento do judiciário brasileiro, através das decisões de sua mais alta corte diante do direito à educação, considerado por muitos teóricos, sobretudo os de 
cunho mais socialistas, como solucionador da maioria dos problemas sociais do país e que, no entanto, ainda é negligenciado pelo poder público.

Todo o material estudado constitui um cabedal documental que credencia essa pesquisa. Sem dúvidas que colocar em pauta o tema da intervenção do judiciário na efetivação do direito à educação é uma questão relevante, pois se trata de tentar explicitar a atuação do poder judiciário, enquanto promotor da justiça social em favor de todos os brasileiros, principalmente da parcela cuja voz é silenciada pelas próprias condições existenciais.

A busca de respostas sobre a atuação do poder judiciário no sentido de forçar o cumprimento do direito constitucional à educação, conforme as indagações que se tem feito, teve por base primeiramente a Constituição Federal, no tocante à educação enquanto direito social, em seguida as cláusulas da reserva do possível e do mínimo existencial, apontadas pela doutrina como direcionadoras da efetivação dos direitos sociais. Para que então, só depois de construído um apoio com a combinação de doutrina e legislação através da apresentação do posicionamento de respeitados constitucionalistas e de dispositivos constitucionais que regulam a educação e os direitos sociais em geral, pudesse passar a análise de decisões do judiciário em ações que buscam de alguma forma a concretude do direito à educação.

\section{A EDUCAÇÃO COMO DIREITO SOCIAL}

A Constituição Federal Brasileira reconhece de forma expressa em seu artigo 6 a natureza jurídica de direito social à educação e consequentemente o seu caráter de direito fundamental da pessoa humana.

Mesmo sendo certo que toda norma constitucional é dotada de eficácia, ou que, como no postulado de Silva (2008, p. 81 apud ARAÚJO, 2011, p. 16) "[...] não há norma constitucional alguma destituída de eficácia". Pode-se afirmar que um direito quando constituído de caráter social gera ao Estado um compromisso ainda maior com a sua efetivação, e consequentemente ao cidadão um poder maior de cobrança.

Essas peculiaridades dos direitos sociais podem ser extraídas facilmente de seu próprio conceito, como se percebe com o apresentado por Silva (2006) em que os direitos sociais são tidos como prestações positivas proporcionadas pelo Estado 
que tendem a realizar a igualização de situações sociais desiguais, além de disponibilizar ao indivíduo condições fáticas que permitam o efetivo exercício das liberdades fundamentais.

A ideia acima esboçada revela ainda, a efetivação dos direitos sociais como indispensável para o reconhecimento no mundo dos fatos do Estado brasileiro como um Estado Democrático de Direito e de Justiça Social, modelo adotado pela atual Constituição Federal.

Mesmo que no processo de compreensão e efetivação dos direitos sociais com base na atual Constituição deva se considerar a influência do momento histórico em que a mesma surgiu, após a ditadura militar, justificando assim, conforme Cunha Júnior (2014) a relevância atribuída aos direitos sociais na tentativa de resolver uma profunda crise de desigualdade social instalada; não se pode fazer dos mesmos utopia, e nem sequer atenuar o compromisso assumido pelo Estado, principalmente porque, além de listados como sociais no artigo $6^{\circ}$, esses direitos são enquadrados como fundamentais e portanto possuem aplicação imediata nos termos do parágrafo $1^{\circ}$ do artigo $5^{\circ}$ da Constituição, ainda que os pactos internacionais que tratam o tema o prevejam como normas programáticas, e isso, como afirma Duarte (2007) apesar da grande divergência doutrinária quanto ao seu alcance, indiscutivelmente aponta para um tratamento diferenciado e reforçado a ser dispensado a essa categoria de direitos.

Dessa forma, independentemente de encarados como normas programáticas, normas de organização, garantias institucionais ou finalmente direitos públicos subjetivos, as quatro possibilidades de conformação jurídica dos direitos sociais, econômicos e culturais apresentadas por Canotilho (2003), ou qualquer outra classe de normas apresentada pela ampla doutrina constitucional, os direitos sociais no Brasil devem ser tratados com maior atenção e dedicação por parte do Estado, pois essa é a vontade expressa da lei suprema do país.

Tratando especificamente do direito social à educação, verdadeiro foco deste estudo, é importante ressaltar que o mesmo conta com dispositivos relevantes em diversos documentos jurídicos como o Pacto Internacional sobre os Direitos Econômicos, Sociais e Culturais ratificado pelo Brasil em 1991, a Lei n. 9.394/96 Lei de Diretrizes e Bases da Educação Nacional, o Estatuto da Criança e do Adolescente - Lei n. 8.069/90 e o Plano Nacional de Educação, Lei n. 10.172/2011. Porém este artigo tem seus contornos essenciais delineados pela própria 
Constituição Federal, nos dispositivos previsores dos direitos sociais em geral e em seu Título VIII, Da Ordem Social, especialmente nos artigos 205 a 214, onde uma série de particularidades é atribuída ao direito à educação quando comparado aos demais direitos sociais.

Já adentrando nessas particularidades, reconhecemos que apesar da primeira leitura do artigo 205 de nossa Lei Fundamental nos induzir a concluir justamente o contrário ao prever como direito de todos e dever do Estado e da família a ser promovido e incentivado pela sociedade, a educação não pode, tendo apenas esse dispositivo como base, ser reconhecida como um direito subjetivo, e trazemos as lições de Silva sobre o tema:

A educação, direito de todos e dever do Estado e da família, [...] (art. 205; v.
também art.227) -, significa, em primeiro lugar, que o Estado tem que se
aparelhar para fornecer, a todos, os serviços educacionais, isto é, oferecer
ensino, de acordo com os princípios estatuídos na Constituição (art.206);
que ele tem que ampliar cada vez mais as possibilidades de que todos
venham a exercer igualmente esse direito; e, em segundo lugar, que todas
as normas da Constituição sobre educação e ensino hão de ser
interpretadas em função daquela declaração e no sentido de sua plena e
efetiva realização. (2006, p. 184).

De fato, pelas explicações do autor, percebemos claramente que no seu entendimento o artigo 205 da Carta Magna brasileira possui caráter programático e progressivo. Em contrapartida, destacamos o caráter público subjetivo expressamente previsto no artigo 208 da Constituição Federal ao acesso ao ensino fundamental obrigatório e gratuito, inclusive para aqueles que não tiveram acesso a ele na idade própria, e trazemos:

O direito público subjetivo confere a possibilidade do indivíduo transformar a norma que é de caráter geral e abstrata prevista no ordenamento jurídico (direito objetivo) em seu direito (direito subjetivo). Em virtude disso, o direito público subjetivo pode ser considerado como o instrumento jurídico de controle da atuação do poder estatal, possibilitando ao titular do referido direito constranger o Estado a executar o que deve. (DUARTE, 2006, p.267 apud ARAÚJO, 2011, p. 22).

As explicações de Duarte em Araújo revelam que independentemente da classificação adotada aos direitos sociais e consequentemente à educação, ao menos o direito de acesso ao ensino fundamental pode ser exigido pelo indivíduo ao Estado sem maiores questionamentos, pois esse, indiscutivelmente é um direito público subjetivo o que, como afirmado por Silva (2006) equivale a reconhecer que é 
direito plenamente eficaz e de aplicabilidade imediata, e assim, exigível judicialmente, se não for prestado espontaneamente.

Destaca-se ainda que, como dito por Tavares (2008) o dever estatal quanto ao direito fundamental à educação não se esgota pelo simples oferecimento de acesso, ressaltando ainda que o acesso inclui o oferecimento de ensino noturno regular, conforme a condição do educando (208, VI), e atendimento ao educando do ensino fundamental com "[...] programas suplementares de material didático-escolar, transporte, alimentação e assistência à saúde" (208, VII); o Poder Público necessita ainda, valorizar o profissional da educação (206, V), além de garantir um padrão mínimo de qualidade (206, VII) .

E embora o artigo 212 da Constituição Federal disponha sobre um sistema próprio de financiamento à educação com vinculação constitucional de receitas, seja pelo grande número de elementos envolvidos para a efetivação desse direito, pela quantidade de cidadãos a que deve alcançar no Brasil, desorganização, ou mesmo corrupção, o certo é que o direito à educação acaba não efetivado para muitos cidadãos brasileiros, o que o coloca diante, assim como fazem em geral os demais direitos sociais, das cláusulas da reserva do possível e do mínimo existencial para ser efetivado.

\section{DELINEAMENTO DA RESERVA DO POSSÍVEL E MINIMO EXISTENCIAL}

Ao tratar dos direitos fundamentais sociais, seja de forma genérica ou de um deles especificamente, é inevitável que se discorra sobre as cláusulas da reserva do possível e do mínimo existencial, pois, embora muitas sejam as divergências doutrinárias acerca de tais direitos, uma de suas características é incontroversa: os direitos sociais pressupõem grandes disponibilidades financeiras por parte do Estado.

Conforme Araújo (2011), Canotilho, também defendendo que a efetivação dos direitos sociais depende de recursos econômicos do Estado, foi quem nomeou como "reserva do possível" o limite trazido pelo Tribunal alemão ao entender, enquanto discutia sobre a possibilidade do judiciário criar vagas na Faculdade de Medicina para estudantes habilitados no vestibular, mas não classificados, que o reconhecimento dos direitos sociais depende da disponibilidade dos recursos públicos necessários para a satisfação das prestações materiais que constituem seu 
objeto, o que passa a ser considerado verdadeiro limite fático à efetivação dos direitos sociais prestacionais.

O fato de os direitos sociais exigirem grande disponibilidade financeira do Estado, fez com que a construção dogmática reserva do possível fosse difundida e aderida rapidamente por diversos países, dentre eles o Brasil, para explicar as limitações sofridas por esses direitos em sua efetividade.

Porém, embora se tenha consciência da grande contribuição que o direito estrangeiro proporciona ao Brasil, nesse caso, é necessário se ter claro, nas palavras de Araújo, que:

A cláusula da reserva do possível não pode ser aplicada no Brasil tal como foi concebida e aplicada pelo Tribunal Constitucional Federal Alemão, pois diferentemente do caso brasileiro, os direitos socais na Constituição alemã não se encontravam positivados expressamente. (2011, p. 86).

Além da forma distinta dada aos direitos sociais pelas legislações alemã e brasileira, é importante mencionar que até mesmo a concepção original da cláusula "reserva do possível" é questionada. O próprio Canotilho (2003, p. 481) dispõe sobre o prejuízo que pode ser acarretado aos direitos fundamentais sociais com a aceitação de sua vinculação aos cofres públicos, afirmando que: "Um direito social sob "reserva dos cofres cheios" equivale, na prática, a nenhuma vinculação jurídica"; o que o faz, visando atenuar esta conclusão desoladora, afirmar que em sede de direitos sociais, o Estado deve na verdade vincular-se à garantia do mínimo social, ou, mínimo existencial. E assim, o mínimo existencial, acaba por se caracterizar como limite à cláusula da reserva do possível.

Barcellos (2008, p. 278 apud ARAÚJO, 2011, p. 76) entende que: “o mínimo existencial é formado pelas condições materiais básicas de existência e corresponde a uma fração nuclear da dignidade da pessoa humana".

Também defendendo que a garantia do mínimo existencial deriva do dever inafastável dos poderes públicos de assegurar a dignidade da pessoa humana e não de uma proteção jurídico-constitucional especial dos direitos sociais, Paulo e Alexandrino (2013) dizem que o implícito postulado constitucional do mínimo existencial como sendo corolário direto do princípio da dignidade da pessoa humana, não permite, ainda que sob a alegação de insuficiência de recursos financeiros, que o Estado negue o direito a prestações sociais mínimas necessárias a existência humana digna, tais como o direito à saúde e a educação. 
Assim, ainda que a escassez de recursos financeiros inviabilize muitas vezes a promoção de políticas públicas tornando a reserva do possível limite fático real à concretização dos direitos sociais, segundo Alexy (2001 apud CUNHA JÚNIOR, 2014), prioridades entre os diversos objetivos a serem alcançados podem ser elencadas e o orçamento organizado a partir da concepção de que determinados gastos, de menor urgência social, podem ser diferidos em favor de outros, reputados indispensáveis e emergenciais.

Além do mais, como bem esclarece Paulo e Alexandrino (2013, p. 253) a cláusula da reserva do possível não significa um "salvo conduto" para o Estado, que pode vir a deixar de cumprir suas obrigações sob a alegação genérica de que "não existem recursos suficientes". A não efetivação, ou efetivação apenas parcial, de direitos constitucionalmente assegurados somente se justifica se, em cada caso, for possível demonstrar a impossibilidade financeira de sua concretização pelo Estado.

Fazendo uma rápida análise das cláusulas da reserva do possível e do mínimo existencial aplicadas na efetivação do direito social à educação de forma específica, é preciso que se volte às particularidades desse direito social.

Primeiramente, é importante ressaltar que o próprio Constituinte garantiu a destinação de recursos para viabilizar a realização do dever do Estado com a educação, de modo especial com o ensino fundamental. Segundo o artigo 212 da Constituição, a União tem o dever de aplicar ao menos 18\%, os Estados, Distrito Federal e Municípios 25\% da receita resultante de impostos, na manutenção e desenvolvimento do ensino.

Essas porcentagens tornam ainda mais complexa, em sua própria concepção, a aplicação da cláusula da reserva do possível quando se tratar da efetivação do direito a educação, e ressaltam a importância atribuída à educação, pois, conforme Sarlet (2012) representam a maior fatia do orçamento público, podendo ser aumentadas já que se tratam de verba orçamentária mínima e o parágrafo $5^{\circ}$ do artigo 212 traz o salário educação como contribuição social com recursos destinados para o financiamento adicional ao ensino, de forma que toda essa previsão orçamentária específica pode tornar mais elástica a concepção de mínimo existencial dentro desse direito.

Destacando também, que o parágrafo $1^{\circ}$ do artigo 208 da Constituição, prevê que: "O acesso ao ensino obrigatório e gratuito é direito público subjetivo", parecenos viável, ao menos em princípio, a ideia de Barros (1996 apud SARLET, 2012) de 
que é possível a condenação do poder público, numa demanda de natureza cominatória, a uma obrigação de fazer, por exemplo, a construção de uma escola, ou mesmo a matrícula em escola particular as expensas do poder público, na hipótese de não ser possível o reconhecimento de um direito de acesso ao ensino fundamental público gratuito no caso de inexistentes ou, comprovadamente, insuficientes os recursos materiais disponíveis (escolas, salas de aula, vaga, professores etc.), sendo ainda, possível exigir do Estado o pagamento de uma indenização pela omissão, que, no entanto, como reconhece o autor, não tem a capacidade de substituir a falta de estudo.

Porém, toda a explanação já realizada até aqui acerca do direito social à educação e a aplicação das cláusulas da reserva do possível e do mínimo existencial em sua efetivação deu-se apenas com o intuito de situar-nos no tema, optamos por não adotar conceitos fechados a fim de não delimitarmos a classificação e aplicação do direito à educação em si, ou das cláusulas a que está sujeito; isso para que se possa analisar sem prejuízos, a luz dos julgados do Supremo Tribunal Federal, como na prática esse direito, aqui incluído seus limitadores e reguladores, é tratado pelo judiciário brasileiro, bem como quais têm sido as interpretações de nossa Corte Suprema frente às previsões constitucionais na seara educacional.

\section{O POSICIONAMENTO DO SUPREMO TRIBUNAL FEDERAL SOBRE A EFETIVAÇÃO DO DIREITO SOCIAL À EDUCAÇÃO}

Apesar de haver previsão do direito à educação em diversos documentos jurídicos, bem como cláusulas amplamente adotadas na doutrina, delimitadoras e regulamentadoras desse direito, e, sobretudo reconhecimento constitucional expresso da educação como um direito fundamental de caráter social, ainda há muita polêmica quando se trata da atuação do judiciário na efetivação desse direito, muito por conta das divergências quanto à sua classificação, mas principalmente quanto ao delineamento de seu objeto e às limitações a que ele está sujeito, além dos limites impostos ao próprio poder judiciário.

Diante disso, e também considerando que, como já disse Bobbio (1992, p. 25): "O problema do nosso tempo, com relação aos direitos do homem, não é mais o de fundamentá-los, e sim o de protegê-los". Torna-se imperioso analisar, à luz de 
seus julgados, qual o comportamento do judiciário frente às demandas envolvendo o direito social à educação para impedir que apesar de expressamente previsto em nossa Carta Magna, ele seja continuamente violado.

Para isso, foram selecionados cinco julgados do Supremo Tribunal Federal, por ser este o guardião da Constituição Federal, que têm como tema o direito social à educação.

Os casos foram buscados no banco de dados do sítio eletrônico do Supremo Tribunal Federal (www.stf.jus.br) através da ferramenta "jurisprudência" e restringindo o universo temporal entre 01 de janeiro de 2004 (ano de julgamento da ADPF 45, decisão emblemática no trato dos direitos sociais em geral) e 31 de setembro de 2014 (data de encerramento das buscas para início da análise dos dados), utilizando-se da expressão "direito fundamental a educação" no campo "pesquisa livre"; e selecionados, dentre o acervo encontrado, considerando a diversidade de objetos pleiteados que se desejava apresentar dentro da temática trabalhada e com base no reconhecimento que a doutrina especializada e o próprio Tribunal atribuem aos mesmos através de citações.

Assim, chegou-se aos: Agravo Regimental no Recurso Extraordinário no 410.715-5; Agravo Regimental no Recurso Extraordinário no 594.018-7; Ação Direta de Inconstitucionalidade no 1.698; Agravo Regimental no Recurso Extraordinário 603.575 e Recurso Extraordinário com Agravo no 832.007, que passam a ser analisados em ordem cronológica.

\section{a) CASO 1: Agravo Regimental no Recurso Extraordinário no 410.715-5}

Julgado em 22 de novembro de 2005 pela Segunda Turma do Supremo Tribunal Federal, o Agravo Regimental analisado foi interposto contra decisão que deu provimento a recurso extraordinário deduzido pelo Ministério Público do estado de São Paulo que possuía como objeto pedido de atendimento em creche de uma criança no município de Santo André.

O Município alegou no agravo que a manutenção de ensino não pode ser apenas a ele atribuída, nem mesmo o atendimento a crianças em creches e escolas de educação infantil. Destacou que o caso envolve questões de orçamento e disponibilidade e afirmou caracterizar as decisões judiciais que obrigam as 
matrículas de crianças em creches, indevida ingerência do Judiciário no poder discricionário do Executivo.

Contrariando o primeiro argumento, o Relator, Celso de Melo, destacou que o direito a atendimento em creche e pré-escola a criança de até seis anos de idade é assegurado pelo próprio texto constitucional, em seu artigo 208, inciso IV, e que a execução desse dever jurídico é de prioridade dos municípios, segundo o parágrafo $2^{\circ}$ do artigo 211 da Constituição.

Sustentou ainda que, sendo a educação um dos direitos sociais mais expressivos, e a educação básica um direito público subjetivo do particular, a omissão do poder público se configuraria em uma inconstitucionalidade, o que acabou também por fazer gancho para a sua contra argumentação à alegação do Município de invasão de poderes por parte do judiciário ao proferir decisão que obriga a matrícula de criança em creche, quando após assumir que a formulação e implementação de políticas públicas cabem primariamente aos poderes Legislativo e Executivo, profere:

Impende assinalar, no entanto, que tal incumbência poderá, atribuir-se, embora excepcionalmente, ao Poder Judiciário, se e quando os órgãos estatais competentes, por descumprirem os encargos político-jurídicos que sobre eles incidem em caráter mandatário, vierem a comprometer, com tal comportamento, a eficácia e a integridade de direitos individuais e/ou coletivos impregnados de estatura constitucional, como sucede na espécie ora em exame.

Assim, Celso de Melo explica que mesmo não sendo originariamente função do Poder Judiciário a implementação de políticas públicas, não há desrespeito à tripartição de poderes, quando o tribunal o faz diante do não cumprimento por parte dos órgãos estatais de suas funções, a fim de evitar ou sanar o prejuízo à eficácia e à integridade dos direitos.

A respeito da reserva do possível, também suscitada pelo Agravante, o Ministro reconhece que a efetivação dos direitos sociais depende de recurso financeiro, tanto que diz não ser possível a exigência de sua imediata efetivação em caso de comprovação objetiva da incapacidade econômico-financeira da pessoa estatal. Porém, adverte que a cláusula da reserva do possível não pode ser invocada pelo Estado de forma dolosa, com a pretensão de exonerar-se de obrigações constitucionais a ele impostas, principalmente quando isso puder gerar a nulificação ou aniquilação dos direitos fundamentais. 
Todos os demais ministros seguiram o voto do relator em seus próprios termos, negando assim, provimento ao recurso de agravo por unanimidade de votos.

Cabe ressaltar ainda quanto a esse julgamento, que o mesmo contribuiu com a pacificação do entendimento do Supremo Tribunal Federal acerca da questão das vagas em creches públicas, se não o mais, um dos temas mais discutidos no STF envolvendo a educação, havendo inclusive uma série de julgados abrangendo o mesmo direito que fazem menção ao voto de Celso de Melo no presente agravo, todos pelo reconhecimento do direito a vaga e a sua imediata concretude.

\section{b) CASO 2: Agravo Regimental no Recurso Extraordinário no 594.018-7}

O Agravo Regimental analisado foi interposto diante de Recurso Extraordinário responsável pela alteração de decisão que negou provimento à ação civil pública ajuizada pelo Ministério Público estadual objetivando compelir o Estado a suprir a carência de professores em unidades de ensino público, localizadas no Município de São Gonçalo, Rio de Janeiro.

Proferida em 23 de junho de 2009 e tendo o ministro Eros Grau como relator, o presente julgamento ressaltou o caráter de direito fundamental da educação e apresentou o entendimento de que os direitos sociais estão previstos em normasprogramáticas.

No voto de Celso de Melo, porém, explicou-se:

[...] o caráter programático das regras inscritas no texto da Carta Política não pode converter-se em promessa constitucional inconsequente, sob pena de o poder público, fraudando justas expectativas nele depositadas pela coletividade, substituir, de maneira ilegítima, o cumprimento de seu impostergável dever, por um gesto irresponsável de infidelidade governamental ao que determina a própria Lei Fundamental do Estado.

As palavras do Ministro alertam ao fato de que, não é porque estão previstos em normas programáticas que os direitos sociais não comprometem o Estado, até mesmo porque caso assim fosse, não poderiam ser tidos como direitos. Posição que também fundamenta o entendimento do Supremo Tribunal Federal de que a sua atuação na concretude desses direitos não viola a separação dos poderes, alegação inclusive, do agravo em questão.

Quanto à separação de poderes também se trouxe, mais uma vez, o entendimento fixado pelo Supremo de que mesmo pertencendo inicialmente aos 
Poderes Legislativo e Executivo a prerrogativa de formular políticas públicas, é possível que o Poder Judiciário determine, excepcionalmente, a sua implementação, especialmente quando se trata das políticas públicas definidas na Constituição, haja vista que a omissão dos órgãos por elas responsáveis compromete a eficácia e integridade dos direitos sociais, que possuem estrutura constitucional.

Já o reconhecimento pelo Ministro da gradualidade do processo de concretização dos direitos sociais no presente julgado, trouxe à baila no Tribunal as cláusulas da Reserva do Possível e do Mínimo Existencial, já que essa gradualidade é justamente explicada pela dependência às possibilidades orçamentárias do Estado a que está subordinada a efetivação desses direitos.

Trabalhando com a ideia da reserva do possível, o relator traz a ponderação de Barcellos (2002), e chega à cláusula do mínimo existencial, ao explicar que, mesmo não se podendo ignorar que os recursos são esgotáveis, não se pode esquecer que a finalidade do Estado ao obter recursos é na verdade a realização dos objetivos fundamentais da Constituição, o que se dá através de obras, prestação de serviços e demais políticas públicas, e que a principal meta de nossa Carta Magna é assegurar as condições da dignidade humana, sendo necessária para isso a garantia de elementos fundamentais dessa dignidade, ou seja, o mínimo existencial, devendo ser estes, portanto, estabelecidos como alvos prioritários dos gastos públicos.

Tendo, em tese, esses fundamentos, a Segunda Turma do Supremo Tribunal Federal, por unanimidade de votos negou provimento ao agravo regimental, mantendo a decisão que obriga o Estado a suprir a carência de professores, já que como imposto pelo artigo 205 da Constituição, é seu dever propiciar meios que viabilizem o exercício do direito a educação.

\section{c) CASO 3: Ação Direta de Inconstitucionalidade no 1.698}

Trata de ação ajuizada pelos partidos políticos PT, PC do B e PDT em 1997 e julgada em 2010, onde se atribuía ao Presidente da República omissão em relação ao disposto nos artigos 6ำ 23, inciso V, 208, inciso I e 214, inciso IV da Constituição da República ao manter-se inerte frente ao dever de erradicar o analfabetismo no país e implementar o ensino fundamental obrigatório e gratuito a todos os brasileiros. 
Para embasar suas alegações os requerentes usaram dados do Anuário Estatístico Brasileiro de 1995, e foi justamente por meio de comparação desses dados com os de 2007, que a relatora, Ministra Carmem Lúcia, mesmo ressaltando o estado precário da educação brasileira, entendeu não poder falar em omissão do poder público, já que o número de analfabetos no país havia caído de $15 \%$ para $11,3 \%$ no período.

A relatora apresentou ainda dados fornecidos pelo Ministro da Educação e pelos sítios eletrônicos do Governo Federal, ressaltando os programas de melhoria de ensino, como o Brasil Alfabetizado e o Bolsa Família, além do aumento de receitas destinada à educação e de número de vagas em escolas, bem como a abertura de novas escolas técnicas.

Em seu voto o Ministro Ayres Brito, ressaltou que o indeferimento da analisada ação, não obsta a possibilidade de controle de constitucionalidade por omissão de políticas públicas no campo da educação, e confirmando não haver contingenciamento de despesas na área da educação por parte do poder público, acompanhou a relatora.

Também acompanhando Carmem Lúcia, Cezar Peluso afirmou não ver possibilidade de o Tribunal adotar postura diversa, sem que se invista na função de administrador.

Já Marco Aurélio, naquele que seria o único voto pela procedência da ação, volta a mencionar aquilo que foi reiteradamente questionado pelos demais ministros: a observação dos percentuais orçamentários mínimos estabelecidos pela Constituição em termos de educação. Mas, contrariando seus colegas, afirma que a circunstancia de se observar o piso previsto na Carta da República é o mínimo, de forma que não o conduz a assentar que não há omissão do Poder Público, que ainda tanto deve à sociedade no sensível campo da educação.

Apesar do posicionamento de Marco Aurélio pela caracterização da insuficiência dos esforços do Estado como omissão inconstitucional a ADI foi julgada improcedente. Sendo válido trazer a ressalva apresentada por Gilmar Mendes de que a improcedência da ação não representa uma satisfação quanto à efetivação do direito à educação no Brasil, significa apenas que, ainda que insuficientes, os esforços do Governo para combater o analfabetismo e universalizar o ensino não podem ser ignorados. 


\section{d) CASO 4: Agravo Regimental no Recurso Extraordinário no 603.575}

Julgado em 20 de abril de 2010, o Agravo Regimental analisado adveio de recurso extraordinário interposto contra acórdão que cassou antecipação de tutela deferida pelo juízo "a quo", extinguindo ação civil pública ajuizada pelo Ministério Público estadual de Santa Catarina que objetivava ter o Estado-Membro compelido a repassar verbas necessárias ao Município de Benedito Novo para o transporte de crianças da rede estadual de ensino.

O Tribunal "a quo" entendeu que a decisão atacada invadiu a competência que tem o Estado para gerir seus recursos, no mesmo sentido defendido pelo Ministério Público ao alegar no Extraordinário, violação ao princípio constitucional da separação dos poderes.

Tendo inicialmente como base que a Carta Magna consagrou a educação como direito de todos, cabendo à família e ao Estado o dever de promovê-la e incentivá-la inclusive através de programas suplementares de material didáticoescolar, alimentação e transporte, como disposto no artigo 208, VII, o Relator ministro Eros Grau apresentou os argumentos para negar provimento ao agravo, e foi seguido por unanimidade pelos demais ministros.

Como já de praxe em julgados nessa seara, o Ministro trouxe o entendimento fixado pelo Tribunal de que, como direito fundamental de toda criança, a educação infantil não se sujeita em seu processo de concretização, a avaliação meramente discricionárias da Administração Pública, o que refutou a tese do agravante de que a decisão do recurso feria o princípio constitucional da separação dos poderes, tema constantemente discutido nas ações que envolvem direitos sociais como já percebido pelas análises anteriores; pois é um dos embasamentos da prerrogativa excepcional do Poder Judiciário de também formular e executar políticas públicas, a omissão dos demais poderes que comprometa a eficácia e a integridade de direitos sociais impregnados de estatura constitucional.

Citando parte do voto do Ministro Celso de Mello proferido naquela que foi um marco para a efetivação dos direitos sociais, ADPF no 45- MC, DJ de 4.5.04, o relator afirma que a atribuição conferida ao Supremo Tribunal Federal de 
excepcionalmente intervir nas políticas públicas, evidencia o fato de que a Corte não pode demitir-se do importante encargo de tornar efetivos os direitos econômicos, sociais e culturais, sob pena de o Poder Público comprometer de modo inaceitável, a integridade da própria ordem constitucional.

Vencida a problemática da invasão de poderes, o Ministro passa a enfrentar as também recorrentes cláusulas da reserva do possível e do mínimo existencial. Destacando quanto a primeira que, embora a realização dos direitos sociais dependa de um inegável vínculo financeiro subordinado às possibilidades orçamentárias do Estado, não é permitido ao Poder Publico manipular indevidamente sua atividade financeira a fim de criar obstáculo artificial que arbitrariamente inviabilize o estabelecimento e a preservação de condições materiais mínimas de existência dos cidadãos, o chamado mínimo existencial.

Eros Grau no presente caso explica ainda, embora de forma sucinta, a possibilidade de atuação do Judiciário diante da ação ou omissão irregular dos demais poderes frente aos direitos sociais, a qual é justificada com a própria cláusula do mínimo existencial.

Concluindo a análise, é válido destacar que também nessa decisão as normas reguladoras dos direitos sociais foram classificadas como normas programáticas e que o voto do relator encerrou-se com a afirmação de que o grupo daqueles que consideram os princípios constitucionais e as normas sobre direitos sociais como fonte de direitos e obrigações, admitindo assim a intervenção do Judiciário em caso de omissões inconstitucionais está crescendo.

\section{e) CASO 5: Recurso Extraordinário com Agravo no 832.007}

Trata-se de decisão monocrática recente, proferida em 27 de agosto de 2014, sucinta, mas que vale a análise pela riqueza do objeto: agravo contra decisão de inadmissibilidade de recurso extraordinário em face de acórdão ementado pela condenação do Estado a contratação de cuidador para aluno portador de deficiência matriculado em rede regular de ensino.

O Procurador-Geral do Estado de São Paulo alegou ao interpor o recuso violação do artigo $2^{\circ}$ da Constituição Federal que prevê a separação dos poderes, afirmando não ser possível ao Poder Judiciário impor a melhor conduta a ser realizada pelo Poder Executivo. 
Em sua decisão, o Ministro Gilmar Mendes, destacou ser a educação um direito público subjetivo outorgado aos portadores de deficiência mediante atendimento especializado, conforme artigo 208, inciso III, da Constituição da República, assim como artigo 54, inciso III do Estatuto da Criança e do Adolescente.

Quanto ao argumento do Recorrente, o Ministro apresentou o entendimento sedimentado no Supremo no sentido de que, por ser um direito fundamental de toda criança, a educação infantil não sujeita a sua concretização a avaliações meramente discricionárias do Poder Público e, embora residindo originariamente nos Poderes Legislativo e Executivo, a prerrogativa de formular políticas públicas, é possível ao Poder Judiciário determina-las excepcionalmente nas hipóteses de políticas públicas definidas pela própria constituição.

Enfim, no presente caso a fundamentação da decisão continua em torno da ausência de violação ao princípio da separação dos poderes na atuação do Judiciário e da importância do direito pleiteado diante da previsão constitucional da educação como um direito social, importância essa ampliada quando envolvida criança já que a Magna Carta prevê delineamentos específicos para o direito á educação infantil e fundamental.

Porém, esse julgamento merece atenção diante do direito especifico pleiteado, é certo que uma análise mais profunda do caso deva considerar que o mesmo engloba também direito da criança e dos portadores de necessidades especiais. No entanto, para o objetivo do presente trabalho, é importante concluir, o que se faz apenas com base nos termos da previsão constitucional do direito à educação, é que é proporcionada ao seu titular a busca no judiciário não só do simples acesso a educação por meio de vaga em escola, por exemplo, mas também a instrumentos que proporcionem a sua real e eficiente concretude, como o acompanhamento de cuidador para portadores de deficiência.

\section{DISCUSSÃO DOS RESULTADOS}

Os julgados analisados demonstram que nas ações envolvendo a efetivação do direito à educação, assim como os objetos discutidos: acesso a vagas, educação infantil e transporte; os argumentos trazidos pelas partes são basicamente os mesmos: invasão dos poderes, cláusulas da reserva do possível, mínimo existencial 
e classificação das normas previsoras dos direitos sociais; fazendo com que os fundamentos das decisões também o sejam.

Percebe-se que, mesmo ainda sendo pequeno quando comparado à importância que possui frente à sociedade e seu desenvolvimento, e ao ser humano e sua dignidade, o número de ações que chegam a Máxima Corte envolvendo o direito à educação tem crescido nos últimos anos. Porém a maioria delas busca apenas o acesso à educação, a exigência de sua qualidade parece ser um direito ainda ignorado por seus titulares.

As decisões do Tribunal no geral apresentam fundamentações pacíficas e embasadas nos mesmos doutrinadores, são constantemente reiteradas, havendo ainda vários julgados que apresentam trechos de anteriores.

Tida como uma das alegações contrárias mais frequentes a intervenção do judiciário na efetivação do direito à educação, a invasão dos poderes já tem entendimento sedimentado na Suprema Corte no sentido de que, embora pertença primariamente aos poderes Legislativo e Executivo a prerrogativa de formular e executar políticas públicas, é possível, excepcionalmente quanto àquelas definidas pela própria constituição em que sua omissão comprometa a eficácia e a integridade dos direitos sociais, ao judiciário determiná-las.

Já acerca da classificação da norma previsora de direito social, o Supremo cita em diversos julgados que a mesma é programática, mas ressalta em todos eles que sua classe não faz dela isenta de eficácia ou insuscetível de cobrança, apenas esclarece que a sua efetivação se dará em caráter gradual, o que nos arremete as cláusulas da reserva do possível e do mínimo existencial.

No entanto, antes de dispor sobre o tratamento recebido por essas cláusulas cabe destacar que apesar de haver previsão constitucional específica, não se percebe um trato diferenciado ao direito à educação infantil dos demais âmbitos do direito social à educação em termos de fundamentação de decisão. Porém, na resolução da demanda em si, se tem com mais facilidade o provimento de ações que objetivam a concretude da educação infantil do que das demais. Há inclusive entendimento sedimentado na Corte quanto ao reconhecimento da obrigação do Estado de disponibilizar vagas em creches públicas a crianças de até seis anos de idade, o que se deu através do Agravo Regimental no Recurso Extraordinário no 410.715-5 e do Recurso Extraordinário 436.996-6, ambos julgados em 2005. 
Nos demais casos sua decisão costuma mostrar-se ligada aos ditames das cláusulas da reserva do possível e do mínimo existencial, já que, não se pode ignorar que o direito à educação, como um típico direito social, possui a sua efetividade condicionada a existência de recursos financeiros, pois exige um fazer por parte do Estado; assim como, que, em sua essência está vinculado ao núcleo essencial da dignidade da pessoa humana. Portanto, muitas vezes, as decisões são resultado do confronto dessas cláusulas.

Diante disso, revela-se que a Corte Superior brasileira, quando provocada, está atuando pela efetivação do direito social à educação, e o faz seguindo um mesmo padrão, de forma que considerando as circunstâncias do caso já se pode deduzir seu fim, o que acaba por revelar também os avanços necessários para o alcance da educação como um direito concreto no Brasil.

\section{CONSIDERAÇÕES FINAIS}

Prevista na atual Constituição Federal como um direito fundamental social, finalmente é reconhecida pelo aparato normativo brasileiro, a importância da educação na construção do desenvolvimento social e a sua essencialidade para a dignidade da pessoa humana.

No entanto, como percebido no decorrer do trabalho, embora essa previsão tenha se dado de forma expressa e exista dispositivos que estabeleçam a sua aplicabilidade imediata e tracem os contornos da concretude desse direito, além de ser evidente o seu não cumprimento na vida de grande parte dos brasileiros; ainda há polêmica em torno da intervenção do judiciário na sua efetivação.

Com as análises jurisprudenciais realizadas, porém, se percebe que quanto à legitimidade da atuação do judiciário, a discussão é algo muito mais teórico do que fático, pois, ainda que a doutrina a questione, utilizando para isso o princípio da separação dos poderes, o Judiciário não tem se escusado de exercer o seu papel de garantidor dos direitos do cidadão, quando provocado não só tem julgado as demandas envolvendo o direito social à educação, como na maior parte das vezes tem decidido pela sua concessão.

Já em relação aos limites práticos impostos à atuação do judiciário, esses sim são reais e precisam ser admitidos, o que nos leva às cláusulas da reserva do 
possível e do mínimo existencial. A primeira como limitadora do judiciário, e a segunda como sua fonte de ressalva.

Amplamente discutidas na doutrina e apresentadas muitas vezes como fundamento das partes em suas demandas, as cláusulas em questão funcionam como verdadeiros parâmetros de atuação para o judiciário, como se percebe nas decisões analisadas.

Não se pode negar que a efetivação do direito à educação, como um típico direito social, está condicionada a recursos financeiros, mas também não se pode aceitar a mera afirmação de ausência de orçamento como justificativa para o descumprimento de um direito constitucional fundamental. Assim, se justifica a cláusula do mínimo existencial, que consiste exatamente na garantia do mínimo básico para o gozo de uma vida digna, e a educação é, nos dias de hoje, indiscutivelmente necessária para isso.

Dessa forma, percebe-se a dignidade da pessoa humana tanto como fundamento do legislador para prever a educação como um direito fundamental social, como também do judiciário para fazer valer no mundo dos fatos essa previsão constitucional.

Da análise jurisprudencial do Supremo Tribunal Federal tem-se ainda que, apesar de tido pela Corte como previsto em normas programáticas, o direito à educação deve ser efetivado. É reconhecida a necessidade do poder público de se organizar, de construir condições para isso; porém não se pode postergar indeterminadamente sua concretude por conta de suposta falta de condições do Estado. Logo, é direito do cidadão também buscar o judiciário para alcançar o gozo de seus direitos.

Por fim, percebe-se que apesar de poder e dever sofrer intervenções do judiciário para ser efetivado e essa ser de grande valia, o direito à educação jamais será concretizado de forma plena apenas por isso, pois as limitações a que esse poder está sujeito não podem ser por ele vencidas. Não compete a ele, por exemplo, traçar os contornos dos direitos e nem organizar os recursos financeiros do Estado.

Dessa forma, aquilo que muitas vezes é apontado pela doutrina como obstáculo para a intervenção do judiciário em prol do direito à educação, sob a alegação de invasão de competência, é na verdade, na óptica da harmonia ao invés da separação, o caminho para o seu alcance. Ou seja, o direito à educação somente será real e concreto na vida dos brasileiros quando os três poderes - Legislativo, 
Executivo e Judiciário, cumprindo suas devidas funções e respeitando-o na proporção de sua importância, trabalharem conjuntamente com esse propósito.

\section{REFERÊNCIAS}

ARAÚJO, Alessandra Matos de. Legitimidade democrática do controle judicial do direito à educação. 2011. 146f. Dissertação (Mestrado em Direito Constitucional) - Instituto Brasiliense de Direito Público - IDP, Brasília, 2011.

BOBBIO, Norberto. A era dos direitos. 11. ed. Rio de Janeiro: Campus, 1992. p. 25.

BRASIL. Constituição (1988). Constituição da República Federativa do Brasil: promulgada em 5 de outubro de 1988. 4. ed. São Paulo: Saraiva, 1990.

. Lei no 8.069, de 13 de julho de 1990. Dispõe sobre o Estatuto da Criança e do Adolescente e dá outras providências. Brasília, 13 jul. 1990. Disponível em: < http://www.planalto.gov.br/ccivil_03/leis//8069.htm>. Acesso em: 15 abr. 2013.

. Lei no 9.394, de 20 de dezembro de 1996. Estabelece as diretrizes e bases da educação nacional. Brasília, 20 dez. 1996. Disponível em: < http://www.planalto.gov.br/ccivil_03/leis/l9394.htm>. Acesso em: 15 maio 2014.

. Lei $\mathrm{n}^{\circ} \mathbf{1 0 . 1 7 2}$, de 9 de janeiro de 2001. Aprova o Plano Nacional de

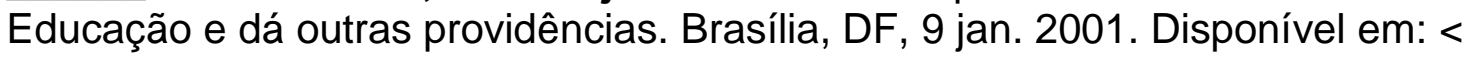
http://www.planalto.gov.br/ccivil_03/leis/leis_2001/l10172.htm>. Acesso em: 10 maio 2012.

. Supremo Tribunal Federal. Agravo em Recurso Extraordinário n.

832.007. São Paulo. Min. Gilmar Mendes. Brasília (DF), 01 set. 2014. Disponível em: $<$ http://www.stf.jus.br/portal/jurisprudencia/visualizarEmenta.asp?s1=000355454\&ba se=baseMonocraticas $>$ Acesso em: 24 out. 2014

. Supremo Tribunal Federal. Agravo Regimental no Recurso

Extraordinário n. 410.715. São Paulo. Reator: Min. Celso de Mello. Brasília (DF), 22 nov. 2005. Disponível em:

$<$ http://redir.stf.jus.br/paginadorpub/paginador.jsp?docTP=AC\&doclD=354801>

Acesso em: 18 out. 2014

. Supremo Tribunal Federal. Agravo Regimental no Recurso

Extraordinário n. 594.018-7. Rio de Janeiro. Relator: Min. Eros Grau. Brasília (DF), 23 jun. 2009. Disponível em:

$<$ http://redir.stf.jus.br/paginadorpub/paginador.jsp?docTP=AC\&doclD=599750>

Acesso em: 18 out. 2014

. Supremo Tribunal Federal. Agravo Regimental no Recurso

Extraordinário n. 603.575. Santa Catarina. Relator: Min. Eros Grau. Brasília, 20 abr. 
2010. Disponível em: <

http://redir.stf.jus.br/paginadorpub/paginador.jsp?docTP=AC\&doclD=611114>

Acesso em: 17 out. 2014

Supremo Tribunal Federal. Ação Direta de Inconstitucionalidade n.

1.698. Relatora: Min. Cármem Lúcia. Brasília (DF), 25 fev. 2010. Disponível em: < http://redir.stf.jus.br/paginadorpub/paginador.jsp?docTP=AC\&doclD=610036> Acesso em: 18 out. 2014

CANOTILHO, José Joaquim Gomes. O Regime dos Direitos Econômicos, Sociais e Culturais. In: CANOTILHO, José Joaquim Gomes. Direito constitucional e teoria da constituição. 7. ed. Coimbra: Livraria Almedina, 2003. p. 471-485.

CUNHA JUNIOR, Dirley da. Dos Direitos Sociais. In: JUNIOR, Dirley da Cunha.

Curso de direito constitucional. 8. ed. Salvador: Editora JusPodivm, 2014. p. 586608.

DUARTE, Clarice Seixas. A educação como um direito fundamental de natureza social. Educ. Soc., Campinas, v. 28, n. 100 - Especial, p. 691-713, out. 2007 Disponível em: <http://www.cedes.unicamp.br >. Acesso em: 18 set. 2014.

PAULO, Vicente; ALEXANDRINO, Marcelo. Direitos Sociais. In: PAULO, Vicente; ALEXANDRINO, Marcelo. Direito constitucional descomplicado. 10. ed. Rio de Janeiro: Método, 2013. p. 243-260

SARLET, Ingo Wolfgang. A eficácia dos direitos sociais na sua dimensão prestacional como problema específico. In: SARLET, Ingo Wolfgang. A eficácia dos direitos fundamentais: uma teoria geral dos direitos fundamentais na perspectiva constitucional. 11. ed. Porto Alegre: Livraria do Advogado, 2012. p. 338-349.

SILVA, José Afonso da. Dos Direitos Sociais In: SILVA, José Afonso da.

Comentários contextual à constituição. 2. ed. São Paulo: Malheiros, 2006. p. 183201.

TAVARES, André Ramos. Direito Fundamental à Educação. In: SOUZA, Cláudio Pereira de; SARMENTO Daniel (orgs.). Direitos sociais: fundamentos, judicialização e direitos sociais em espécie. Rio de Janeiro: Lumen Juris Editora, 2008. p. 771-788. 